\title{
Epidemiological studies on bacterial respiratory infections in commercial poultry of district Hyderabad, Sindh, Pakistan
}

\author{
Abdul Gaffar Abbasi ${ }^{1}$, Shahid Hussain Abro ${ }^{1}$, Asghar Ali Kamboh ${ }^{1}$, \\ Dildar Hussain Kalhoro ${ }^{1}$, Muhammad Qasim Mazari ${ }^{1}$, Muhammad \\ Bilawal Arain ${ }^{2}$, Waseem Ali Vistro ${ }^{3}$, Muhammad Azhar Memon ${ }^{4 *}$, \\ Muhammad Ali Memon ${ }^{4}$ and Sarfiraz Hussain Depar ${ }^{5}$ \\ 1. Department of Veterinary Microbiology, Sindh Agriculture University Tando Jam-Pakistan \\ 2. Department of Veterinary Pharmacology, Sindh Agriculture University Tando Jam-Pakistan \\ 3. Department of Anatomy and Histology, Sindh Agriculture University Tando Jam-Pakistan \\ 4. Department of Veterinary Parasitology, Sindh Agriculture University Tando Jam-Pakistan \\ 5. Department of Poultry Husbandry, Sindh Agriculture University, Tando Jam-Pakistan \\ *Corresponding author's email: azharmemon800@gmail.com \\ Citation \\ Abdul Gaffar Abbasi, Shahid Hussain Abro, Asghar Ali Kamboh, Dildar Hussain Kalhoro, Muhammad Qasim \\ Mazari, Muhammad Bilawal Arain, Waseem Ali Vistro, Muhammad Azhar Memon, Muhammad Ali Memon and \\ Sarfiraz Hussain Depar. Epidemiological studies on bacterial respiratory infections in commercial poultry of district \\ Hyderabad, Sindh, Pakistan. Pure and Applied Biology. Vol. 9, Issue 2, pp1253-1265. \\ http://dx.doi.org/10.19045/bspab.2020.90131
}

Received: 01/10/2019 Revised: 02/01/2020

Accepted: 17/01/2020

Online First: 12/02/2020

\section{Abstract}

Respiratory infection causes high economic and production losses in commercial poultry therefore, this study was conducted to record the prevalence of bacterial infection in commercial poultry farms. Out of 100 samples, nasal $(n=50)$, tracheal $(n=50)$ were collected from selected areas Detha, Moosa Khatian, Tando Hyder and Tando Qaisar, $\mathrm{n}=25$ from each. From 100 samples $\mathrm{n}=48$ samples were found positive. From total of 48 positive samples, 105 bacterial isolates were found, the overall proportion of bacterial organisms from nasal and tracheal were staphylococcus aureus $15.23 \%(\mathrm{n}=16)$, Streptococcus spp $20 \%$ $(\mathrm{n}=21)$, E coli $38.09 \%(\mathrm{n}=40)$, Salmonella spp $15.23 \%(\mathrm{n}=16)$, Pseudomonas aeruginosa $9.5 \%(\mathrm{n}=10)$ and Klebsiella spp $1.90 \%(\mathrm{n}=2)$. Area wise prevalence of bacterial respiratory infections was recorded in Detha $64 \%$ (16/25), Moosa khatian 48\% (12/25), Tandohyder 44\% (11/25) and Tando Qaisar 36\% (9/25). Highest prevalence was recorded in age group of $0-2$ weeks $52.08 \%$ (25/46), followed by $29.16 \%(14 / 29), 18.75 \%$ $(25 / 9)$ in 2-4 week and > 4-week age group respectively. Maximum outbreaks of bacterial respiratory infections were recorded in month of January 50\% (30/60) while minimum in March 45\% (18/40). Maximum percentage obtained from large scale farming $62.22 \%$ (28/45) followed by $36.36 \%$ (20/55) in small scale farming respectively. In present investigation it has concluded that overall isolates prevalence of E-coli spp was found maximum. Highest rate of prevalence found in Detha region. 0-2 weeks age group is more effected as compared other age groups. High rate of prevalence for bacterial respiratory infections observed in January as compared to March.

Keywords: Bacterial respiratory infections; Epidemiological studies; Hyderabad; Poultry 


\section{Introduction}

In Pakistan commercial poultry forming was established in early (1960's) which represent one of the largest contributions in GDP (1.3\%) of Pakistan [1]. Twenty-five thousand commercial poultry farms of breeder, layer and broiler birds in our country, housing 10.19 million breeders, 39.46 million layer and 722.39 million broilers [2]. Respiratory tract infections are most commonly found in the poultry. In most of the cases, respiratory tract diseases are multi systemic diseases seen in a poultry flock and it may be the main disease with less participation of other organs of the systems. In poultry industry respiratory diseases causes largest economic losses due to mortality, high production losses and medicinal costs. Respiratory tract diseases are multifactorial problems which is frequently present and cause by harmful bacterial and viral pathogens in the flock and between the flocks [3, 4]. Mucosal community of microorganisms are present under healthy upper respiratory tract (URT) which include both potential and commensal pathogens which is control by host immune system. Harmful bacteria play primary or secondary role in causing respiratory tract infection in domestic poultry. Usually primary infection is viral then environmental injury to respiratory tract tissue which attract bacterial organisms to inhabit the respiratory organism [5-7]. The causes of respiratory tract diseases are more complex because more than one pathogen is involving at same phase and they cause large economic losses both in relations of cost of medicine and production [8]. Diseased birds showed respiratory or other signs and lesions i.e. poor growth, respiratory distress, cough, decrease in egg production and less weight gain which is important to largest economic losses [9].

The bacteria which are involved in the respiratory tract infections (RTIs) are Escherichia (Avian pathogenic Escherichia coli), Bordetella (B. avium), Haemophilus (H. paragallinarum) and Pasteurella ( $P$. multocida, $P$. gallinarum, $P$. haemolytica and $P$. anatipestifer) [10], Pseudomonas ( $P$ aeruginosa), Staphylococcus and Streptococcus. Chronic respiratory disease (CRD) in birds and sinusitis in turkey caused by Mycoplasma gallisepticum (MG) [11]. Ornithobacterium rhinotracheale are recently identified which causes respiratory tract contaminations in poultry and other birds [12]. Avian pathogenic Escherichia coli (APEC) cause disease known as colibacillosis disease in poultry. APEC is a complex syndrome which characterized by various lesions i.e. pericarditis, air sacculitis and perihepatitis lesions [13]. Escherichia coli bacteria belongs to the Enterobacteriaceae family. Previously, it was assumed that colibacillosis always a secondary disease but now today (APEC) has become considered as primary pathogens in young chickens [14]. It is also recommended that (APEC) could be represent a zoonotic risk by causing disease also in humans $[15,16]$. Serotypes of Escherichia coli is most usually based on two antigens i.e. flagellar and somatic. Up to date there are 60 flagellar $(\mathrm{H})$ and 180 somatic $(\mathrm{O})$ antigens are found [17]. The consequences of carcass rejection at slaughter and high mortality rates in chicken cause important economic losses in the poultry sector worldwide [18].

All avian species of any ages of birds are susceptible to APEC, but they are most severe in young birds [14]. APEC could be transmitted both horizontally and vertically and cause high chick mortality in newly hatched chicks. The most common conclusions of APEC infections are yolk sac infection and omphalitis as well as coli septicemia [19, 20].

Bordetella causes bordetellosis which is a highly contagious infection of the respiratory tract in young poultry. It is a gram-negative, non-fermentative, firmly aerobic, motile bacterium Bordetella avium (B. avium). In the turkey's respiratory tract, hemogglutinin, 
autotransporter protein and fimbriae which is produce by B.avium which play important role in the adherence the tracheal epithelial cells [21-23]. Interestingly, the fimbria locus of $B$. avium is regulated in response to temperature $\left(37^{\circ} \mathrm{C}\right)$, and only under such conditions the bacterium is capable to adhere to the host's respiratory epithelium [22]. In diagnosis of bacterial infections, the golden standard is bacterial culture. There are reports in the literature about molecular diagnosis of bacterial infections as well as Bordetella spp $[24,25]$.

Avibacterium paragallinarum, once known as Haemophilus paragallinarum pathogen causes an acute respiratory disease in chickens referred as Infectious coryza (IC). After phenotypic and genotypic investigation, taxonomic changes resulted in its designation as Avibacterium paragallinarum [26]. IC is a typical commercial disease resulting in deprived growth performance in broilers and a decline in egg production in the layer, serous nasal discharge in the upper respiratory tract and edema of the face and wattle in chickens regardless of age are included as major clinical signs [27].

Pseudomonas aeruginosa is an opportunistic organism which is predominant in water, as it induces resistance to various antibiotics medicine and disinfectant. It is a classic adaptable pathogen, in addition to its armory of putative virulence factors plus plasmid acquired resistance [28]. Pseudomonas aeruginosa is the Gram-negative bacteria present in nosocomial infections, especially in neutropenic immunocompromised causing various spectra of infections, cystic fibrosis infection and tissue [29].

In avian host, respiratory disease complex is involved by some microorganisms of the genus Pasteurella i.e Pasteurella multocida, Pasteurella haemolytica, Pasteurella anatipestifer and Pasteurella gallinarum [10]. In poultry and wild birds, Pasteurella multocida subspp multocida was most significant pathogen that cause disease fowl cholera [30]. Pasteurella multocida cause severe disease in poultry spp so that economic loss occurs [31-33]. Fowl Cholera is septicemic infection which is related with low mortality and high morbidity in ducks and chickens. In acute cases, signs or symptoms of Fowl Cholera are mostly existing within few hours earlier to the death i.e. cyanosis of comb, ruffled feathers, fever, wattles, mucus discharge from nose, ears and mouth are signs in chicken [33]. In $P$. multocida there are five serotype which as A, $\mathrm{B}, \mathrm{E}, \mathrm{F}$ and these serotypes is related with specific host e.g., fowl cholera cause by serotype A in avian spp [34]. Fowl cholera was susceptible in young age of chickens in flock as compare to others age [35].

Staphylococcus infection denotes to a variety of diseases in poultry caused by staphylococci bacteria [36]. There are about 20 different species of staphylococcus are isolated, $S$. aureus is the only species of staphylococcus which have veterinary importance in breeders. It is a significant opportunistic pathogen which may cause life threatening illness in variety of animal species. In every region of the world Staphylococcus aureus can causing health care associated and community-acquired infections [37]. Staphylococcus aureus is a gram positive, coagulase positive coccoid cell in the family Staphylococcaceae [38] commonly found in the breeder house, environment and can be isolated from the litter, dust and feathers of chickens. In meat, toxigenic $S$. aureus possess a potential health threat to consumers though, as a part of risk analysis of meat and poultry products the identification of such strains should be used [39]. During growth on a variety of foods Staphylococcus aureus is a recognized as food borne pathogen that produces heatstable enterotoxins, including meat and 
poultry products, eggs, cream-filled pastries, potatoes, and some salads [40].

Streptococci are coccoid bacteria that have its place to the phylum Firmicutes, class Bacilli, order lactobacillales and the family Streptococcaceae [41]. Streptococcus species have been related with infections without obvious clinical signs including growth depression and increased mortality [42]. $S$. equi ssp. Zooepidemicus is most commonly associated specie with diseases in poultry among streptococcus species. In addition, many species seem to share several hosts. Though, major genetic alterations seem to exist between species, and a combination of phenotypic and molecular methods is likely to permit more certain diagnosis [43].

Mycoplasma spp cause mycoplasmosis, which causes significant economic losses to the poultry industry all over the world, especially in chickens and turkeys. $M$. gallisepticum (MG) and M. synoviae (MS) are generally two mycoplasma species which are pathogenic in nature $M$. gallisepticum causes chronic respiratory disease in chickens and frequently show loss of appetite, dullness, depression, tendency to huddle together, reduced growth, emaciation, respiratory rales, tracheitis, air sacculitis, coughing, sneezing, exposed mouth breathing, nasal discharges and dyspnea [44]. Isolation of $M$. gallisepticum from tracheal swabs of racing pigeons (Columba livia) has been successful but none of the birds studied showed clinical signs. However, they could play a part in transmission since they are possible carriers of the organism $[45,46]$. M.synoviae has always been considered not as much of important as M.gallisepticum in poultry but during the last decade its importance has been underlined in several studies and there is an increased perception to generate $M$. synoviae-free poultry $[47,48]$. Consistently, with the expansion of poultry industry in Pakistan, more frequent incidence of MG infection has been reported during the last decade [49-51]. The Northern region, mainly Abbotabad, Mansehra and Haripur, is central to poultry rearing and production due to its favourable climatic conditions. This region with about more than $30 \%$ of commercial and backyard poultry (more than 80 million poultry) population is known as hub of poultry rearing in Pakistan [52]. Therefore, this is study is planned to isolate and study the prevalence of the different bacterial infections and to identify the risk factors in the commercial poultry farms in District: Hyderabad, Sindh, Pakistan.

\section{Materials and methods}

A total of 100 samples were aseptically collected from nostrils and trachea by sterile cotton wool swab from infected chickens based on respiratory clinical symptoms including mucoid or serous nasal discharge, sneezing, lacrimation, conjunctivitis and facial swelling from randomly selected areas such Detha, Moosa Khatian, Tando Qaisar and Tando Hyder, (n=25 from each). Samples were collected according to the age of chicken (i.e. 0-2 weeks, 2-4 weeks and > 4 weeks). Signs and symptoms of birds assumed for respiratory infections was recorded. After that the collected samples were transported in cold chain to Central Veterinary Diagnostic Laboratory (CVDL) Tandojam for isolation and identification of bacterial species.

\section{Primary culture}

Nutrient broth media was prepared in to test tube then inoculated nasal and tracheal swabs after that incubated overnight at $\left(37^{\circ} \mathrm{C}\right)$. The collected samples were cultured in nutrient broth media in test tube and incubated overnight at $\left(37^{\circ} \mathrm{C}\right)$. Followed by, it was further cultured in blood agar media in the petri dishes for the subculture which was incubated at $37^{\circ} \mathrm{C}$ for 24 hours. The colonies characteristics were observed. Smears made from each type of colony and stained by Gram's staining method and was examined under light microscope for cell morphology, cell arrangement and staining reaction. 


\section{Sub- cultures}

Purification of culture was done by subculturing part of typical well separated colony on the corresponding medium. The process was repeated several times. The purity of the culture was checked by examining stained smear. Than pure culture was inoculated into nutrient agar slant medium and incubated overnight at $37^{\circ} \mathrm{C}$. Than finally pure culture was stored at $4{ }^{\circ} \mathrm{C}$ for studying cultures and biochemical characteristics.

\section{Media preparation}

The following media were prepared for isolation of different bacterial organisms from collected samples.

\section{Blood media}

The blood agar (BA) was enriched media used to culture those microorganisms that cannot grow easily i.e. these bacteria called as fastidious. The Blood was added to medium for the purpose of growth of

Table 1. Composition of blood agar

\begin{tabular}{|c|c|}
\hline Constituents & Weight \\
\hline Agar & $15 \mathrm{gm}$ \\
\hline Sodium chloride & $5 \mathrm{gm}$ \\
\hline Lab - lemco powder & $10 \mathrm{gm}$ \\
\hline Peptone & $10 \mathrm{gm}$ \\
\hline Distilled water & $500 \mathrm{ml}$ \\
\hline
\end{tabular}

microorganisms. Some bacteria were showed hemolytic properties on blood medium i.e. Staphylococcus spp. It is a differential media which used for isolation of bacterial spp also they were identify by hemolysis of red blood cells (hemolytic property) (Table 1).

\section{Tryptone soya agar}

This medium is used for general purpose and non-selective medium which provide enough nutrients to grow different microorganisms. They are also used to wide range growth media for the cultivation and isolation of different bacterial spp. They contain digestive of enzymatic soybean meal and casein (Table 2).

\section{MacConkeys' Agar (MAC)}

This medium was differential as well as selective media used for the differentiation and isolation of bacterial spp i.e. E. coli. This medium also known as low selective medium and indicator medium (Table 3).

Table 2. Composition of TSA

\begin{tabular}{|c|c|}
\hline Constituents & Weight (gm) \\
\hline Peptic digest of Soya bean meal & 5 \\
\hline Sodium chloride & 5 \\
\hline Pancreatic digest of casein & 15 \\
\hline Agar & 15 \\
\hline
\end{tabular}

Table 3. Composition of MAC

\begin{tabular}{|c|c|}
\hline Constituents & Weight \\
\hline Sodium chloride & $5 \mathrm{~g}$ \\
\hline Peptone & $17 \mathrm{~g}$ \\
\hline chloride Lactose & $10 \mathrm{~g}$ \\
\hline Bile salt & $1.5 \mathrm{~g}$ \\
\hline Crystal violet & $0.001 \mathrm{~g}$ \\
\hline Neutral red & $0.03 \mathrm{~g}$ \\
\hline Protease peptone & $3 \mathrm{~g}$ \\
\hline Agar & $13.5 \mathrm{~g}$ \\
\hline
\end{tabular}




\section{Microscopic examination}

First of all, slide was prepared from cultured agar plates then stained by Grams staining methods after staining procedure slide was observed under microscope using oil immersion. Further confirmation was done by through biochemical test.

\section{Biochemical identification}

Identification of bacterial species was made through different bio chemical tests such as oxidase, catalase, indole coagulase, methyl, Triple Sugar iron, urease and Simmons citrate test were performed according to the standards methods recommended by [53].

\section{Catalase test}

This test was demonstrated that capability of some bacteria to produce enzyme. I.e. catalase enzyme. This catalase enzyme converts hydrogen peroxide in to oxygen and water. The small drops of hydrogen peroxide $3 \%$ solution picked on the slide then cultured bacteria was taken with the help of sterile wire lope on the slide after that mixed both, if bubble produced than catalase test positive.

\section{Coagulase test}

This test was demonstrated that capability of some bacteria to produce enzyme. I.e. coagulase enzyme. This test was used to differentiate Staphylococcus aureus from other species of Staphylococcus. Coagulase enzyme produced by Staphylococcus aureus these enzymes convert fibrinogen in to insoluble fibrin. Positive test was showed clump on the test slide.

\section{Triple sugar iron test}

Why triple sugar iron test (TSI) names because in this test three sugar was used to ferment bacteria i.e. glucose, sucrose and lactose. TSI was used to determine that gram negative bacteria utilized glucose, sucrose and lactose to produce hydrogen sulfide $\mathrm{H}_{2} \mathrm{~S}$. TSI contains ten fragments of sucrose, ten fragment of lactose sugar and one fragment of glucose. Ferrous sulphate and phenol red function as hydrogen sulfide $\mathrm{H}_{2} \mathrm{~S}$ production and acidification of media respectively. If glucose was fermented, then whole media became acidic environment. If the butt remains yellow and slant become red that means it designates bacteria was fermented glucose, but they do not ferment sucrose or lactose. If there was no gas production, it determines that fermented lactose and glucose then acid slant become yellow and acid butt become also yellow. If there was do not fermentation occurs, it indicates there was no change in slant and butt.

\section{Simmons' citrate test}

This test was used to examine that ability of microorganisms to utilize citrate as energy source. This test also used to distinguish gram negative bacilli on the source of citrate consumption. When gram negative organisms consume citrate then ammonium salt convert into ammonia and increase alkalinity of the medium. When $\mathrm{pH}$ above 7.6 was changed in the medium the color changed in to green to blue.

\section{Data analysis}

The data was analyzed, and percentage of observations were obtained using MS Excel (2013).

\section{Results}

In order to record, isolation and prevalence of bacterial respiratory infections, 100 swab samples (tracheal and nasal) were tested from randomly selected areas i.e Detha, Moosa Khatian, Tando Hyder and Tando Qesar 25 samples were collected from each. Out of 100 samples $n=48$ samples found positive for different bacterial isolates responsible for respiratory infections

Isolated and prevalence of bacterial organisms from tracheal and nasal samples

The data shows that, out of 48 positive samples, there were 105 isolates of different bacterial species that causes respiratory infections in chickens. It shows, maximum number of $E$ coli isolates $(\mathrm{n}=40)$, followed by streptococcus spp $(\mathrm{n}=21)$, staphylococcus aureus $(\mathrm{n}=16)$, salmonella spp $(\mathrm{n}=16)$, 
Pseudomonas aeruginosa $(\mathrm{n}=10)$ and klebsiella spp $\quad(\mathrm{n}=2)$ with prevalence percentage of $38.09 \%, \quad 20 \%, \quad 15.23 \%$, $15.23 \%, 9.5 \%$ and $1.90 \%$ respectively. It also shows sample wise proportions of isolates for nasal and trachea that is $58.10 \%$ and $41.90 \%$ respectively (Table 4).

Table 4. Total number and percentage of each isolated bacteria from tracheal and nasal samples (n=100)

\begin{tabular}{|c|c|c|c|c|c|c|c|}
\hline \multirow{2}{*}{ Sample } & \multicolumn{7}{|c|}{ Bacterial isolates } \\
\cline { 2 - 8 } & $\begin{array}{c}\text { Staphylococ } \\
\text { cus aureus }\end{array}$ & $\begin{array}{c}\text { Streptococcus } \\
\text { spp }\end{array}$ & E coli & $\begin{array}{c}\text { Salmonella } \\
\text { spp }\end{array}$ & $\begin{array}{c}\text { Pseudomonas } \\
\text { aeruginosa }\end{array}$ & $\begin{array}{c}\text { Klebseilla } \\
\text { spp }\end{array}$ & $\%$ \\
\hline Nasal n=50 & 10 & 12 & 25 & 8 & 6 & - & 58.10 \\
\hline $\begin{array}{c}\text { Tracheal } \\
\text { n=50 }\end{array}$ & 6 & 9 & 15 & 8 & 4 & 2 & 41.90 \\
\hline $\begin{array}{c}\text { No of each } \\
\text { isolates }\end{array}$ & 16 & 21 & 40 & 16 & 10 & 2 & - \\
\hline $\begin{array}{c}\% \text { of } \\
\text { individual } \\
\text { isolate }\end{array}$ & $15.23 \%$ & $20 \%$ & $38.09 \%$ & $15.23 \%$ & $9.5 \%$ & $1.90 \%$ & - \\
\hline
\end{tabular}

Area vise prevalence for bacterial respiratory infections

Data shows that, area wise prevalence of positive samples for bacterial respiratory Infection, maximum number of positive samples has been observed in Detha $(\mathrm{n}=16)$ $64 \%$, followed by Moosa khatian $(\mathrm{n}=12)$ $48 \%$, Tandohyder $(\mathrm{n}=11) 44 \%$, and $(\mathrm{n}=09)$ $36 \%$ (Table 5).
Age wise prevalence of bacterial respiratory infections

Data shows that, age wise prevalence for bacterial respiratory infections. Maximum positive samples were observed in age group of 0-2 weeks is 25 followed by 14, 09 in ae groups 2-4 weeks, and > 4weeks respectively (Table 6).

Table 5. Area vise prevalence for bacterial respiratory infections

\begin{tabular}{|c|c|c|c|c|}
\hline S. No. & Regions & No of samples & No of positive samples & \% \\
\hline 1 & Detha & 25 & 16 & $64 \%$ \\
\hline 2 & Moosa khatian & 25 & 12 & $48 \%$ \\
\hline 3 & Tando Qaisar & 25 & 9 & $36 \%$ \\
\hline 4 & Tandohyder & 25 & 11 & $44 \%$ \\
\hline Total & & 100 & 48 & \\
\hline
\end{tabular}

Table 6. Age wise prevalence of bacterial respiratory infections

\begin{tabular}{|c|c|c|c|c|c|c|}
\hline \multirow{2}{*}{ Regions } & \multicolumn{2}{|c|}{ 0-2week } & \multicolumn{2}{c|}{$\mathbf{2 - 4}$ weeks } & \multicolumn{2}{c|}{ 4 weeks } \\
\cline { 2 - 7 } & Samples & +ve & Samples & Samples & +ve \\
\hline Detha & 12 & 6 & 7 & 4 & 8 & 2 \\
\hline Moosa Khatian & 10 & 5 & 5 & 2 & 7 & 2 \\
\hline Tando Qaisar & 13 & 6 & 9 & 3 & 5 & 2 \\
\hline Tandohyder & 11 & $\mathbf{2 5}$ & $\mathbf{2 9}$ & $\mathbf{1 4}$ & $\mathbf{2 5}$ & $\mathbf{9}$ \\
\hline Total & $\mathbf{4 6}$ & \multicolumn{2}{|c|}{$\mathbf{2 9 . 1 6 \%}$} & $\mathbf{1 8 . 7 5 \%}$ \\
\hline Percentage & $\mathbf{5 2 . 0 8 \%}$ & \multicolumn{2}{|c}{} \\
\hline
\end{tabular}


Seasonal prevalence for bacterial respiratory infections

Data shows that, seasonal bacterial respiratory infections, maximum number of positive samples observed in January $(\mathrm{n}=30)$ with $50 \%$ while minimum in February $(\mathrm{n}=18)$ $45 \%$ (Table 7).

Table 7. Seasonal prevalence of bacterial respiratory infections

\begin{tabular}{|c|c|c|c|}
\hline Month & No of samples & No of positive samples & Percentage \\
\hline January & 60 & 30 & $50 \%$ \\
\hline March & 40 & 18 & $45 \%$ \\
\hline
\end{tabular}

Prevalence of bacterial respiratory infections on the basis of bird's capacity in farms:

Data shows that, the prevalence of infection on behalf of number of birds in farms, maximum number of positive samples obtained from group of large-scale farming (>2000 birds per form), $(\mathrm{n}=28)$ with $62.22 \%$, while minimum in small scale farming (up to average 2000 birds) $(\mathrm{n}=20), 36.36 \%$ (Table $8)$.

Table 8. Prevalence of bacterial respiratory infections on the basis of farm capacity

\begin{tabular}{|c|c|c|c|}
\hline Groups & No of samples & No of positive samples & Percentage \\
\hline 1. Small scale farming (upto 2000 birds) & 55 & 20 & $36.36 \%$ \\
\hline 2. Large scale farming (>2000 birds) & 45 & 28 & $62.22 \%$ \\
\hline
\end{tabular}

\section{Discussion}

Isolation and identification of bacterial organisms that causes respiratory infections in chickens was done from four different regions of the Hyderabad district, respiratory infections exhibited clinical signs like mucoid or serous nasal discharge, sneezing, lacrimation, conjunctivitis and facial swelling. A total of 100 samples nasal $(n=50)$, tracheal $(n=50)$ collected from four randomly selected areas, 1 . Detha, 2 . Moosa Khatian, 3. Tando Hyder and 4. Tando Qesar, $\mathrm{n}=25$ from each.

Out of 100 samples $n=48$ samples found positive for different bacterial isolates responsible for respiratory infections. From total of 48 positive samples, 105 bacterial isolates we found includes staphylococcus aureus $\mathrm{n}=16$, streptococcus spp. $(\mathrm{n}=21), E$ coli $(\mathrm{n}=40), \quad$ salmonella $\operatorname{spp}(\mathrm{n}=16)$, Pseudomonas aeruginosa $(\mathrm{n}=10)$ and Klebsiella $(\mathrm{n}=2)$. The results of this study were related to previous research by [54] on pathological study on upper respiratory tract infection of chickens and isolation, identification of causal bacteria in which $(\mathrm{n}=116)$ different bacterial isolates were found from nasal and tracheal samples of chickens in Bangladesh.

In this study from a total of 105 isolates a proportion of nasal and trachea is 58\% and $41 \%$ respectively shows higher from another author [55] reported 43\% nasal and 38\% in trachea. This might be due to variation in number of samples, in breed, age, climate, vaccination and management of farms.

In this study the overall proportion of bacterial organisms from tracheal and nasal samples were $15.23 \%$ staphylococcus aureus, $20 \%$ streptococcus sp. $38.09 \%$, Ecoli $15.23 \%$ salmonella, $9.5 \%$ pseudomonas and $1.90 \%$. Klebsella $1.90 \%$. The proportion of staphylococcus aureus in this study is $15.23 \%$ that has isolated from chickens that is lower than [54] who reported $41.4 \%$, it may be due to variation in breed, age. According to Hirsh et al., (2004), Staphylococcus species are present in the upper respiratory 
and upper epithelial surface chickens [56]. In present investigation streptococcus spp has isolated from nasal and trachea of the infected chickens with over all proportion of $20 \%$, evidence related with finding of [57] who found Streptococcus spp from respiratory tract of infected chickens. In this present research, Klebsiella species has been isolated from trachea of infected chickens, it confirms the previous findings of [58] in Sudan which was reported for the isolation of Klebseilla specie from respiratory tract of chicken. The overall proportion of Klebsiella $1.90 \%$ which was much lower than reported by [54] that is $6 \%$ might be due to variation in age, sex, vaccination.

The overall percentage of $\mathrm{E}$ coli in trachea and nasal is $38.09 \%$ that is lower from that reported by [59-61], 65\%, 54\% and $45 \%$ respectively, but higher than $[62,63]$ reported $28 \%$ and $32 \%$ respectively. The proportional percentage of $\mathrm{E}$ coli also related to the research by [64] reported $43.50 \%$ of E. coli infections and by [65] who reported $67 \%$ prevalence of Colibacillosis in commercial poultry.

Four areas for study has been selected for collection of samples, 1. Detha, 2. Moosa Khatian 3. Tando Qaisar, 4. Tandohyder, 25 samples collected from each area, in this investigation the area wise prevalence for bacterial respiratory infections found, maximum percentage of respiratory infections found in Detha 64\%, followed by Moosa Khatian 48\%, Tandohyder $44 \%$ and Tando Qaisar 36\%. Results of present research works found to be closely related with findings by [66] reported comparatively higher prevalence of bacterial respiratory infections $62 \%$ in Sahiwal followed by $59 \%$, $52 \%$ and $55 \%$ in districts Sargodha Manid Bahaudin and Attock respectively. There is relatively little bit difference this might be due to change in area, breed, location of farms and weather.
In the present investigation, it is found that maximum outbreaks for bacterial respiratory infections were $52.08 \%$ in age group $0-2$ weeks, followed by $29.16 \%$ in age group $2-4$ weeks and $18.75 \%$ in age group of $>4$ weeks. According to results the age group 0-2 weeks is more susceptible to respiratory infections it is due to resistance and low immunity level. These result of study supports the report of [65] reported more susceptible of infections $51 \%$ in younger age 0-2 weeks followed by $45 \%$, and $29.24 \%$ in group of 2-3-week age and $>4$ weeks group respectively.

In present research, maximum seasonal prevalence for respiratory infections in chicken were observed in January $50 \%$ followed by March 45\%, these results nearly similar to results by [65] reported $57 \%$ in rainy season while low $43 \%$ in summer, this might be due to increase microbial growth, the fact that microbial propagation increase in humid and moist environment.

The prevalence of respiratory infections in chickens also observed on the basis of number of birds or capacity of farms, maximum out breaks of respiratory infections were seen $62.22 \%$ in large scale farming (>2000 birds) followed by $36.36 \%$ in small scale farming ( upto 2000 birds). Highest prevalence in large scale farming is might be due to overcrowding in result stressful environment produce and susceptibility ratio will be increased.

\section{Conclusion}

From all overall isolated organism it is concluded that the maximum portion of E.coli isolates has observed, highest prevalence of respiratory bacterial infection in chicken was in Detha area of district, comparatively 0-2 week of age group was more affected then 2-4 week and $>4$ week age group, rate of infection was higher in the month of January as compare to march and in large scale farming, farms which having more than 2000 birds are more prone to these infections as compare to small scale farming. 


\section{Authors' contributions}

Conceived and designed the experiments: AG Abbasi, SH Abro, AA Kamboh \& DH Kalhoro, Performed the experiments: AG Abbasi, MB Arain \& MQ Mazari, Analyzed the data: AG Abbasi, M Ali \& WA Vistro, Contributed materials/ analysis/ tools: $\mathrm{SH}$ Abro, SH Depar \& MA Memon, Wrote the paper: MA Memon.

\section{Acknowledgement}

The authors are grateful to the team of Central Veterinary Diagnostic Laboratory for their assistance in this research.

\section{References}

1. Hussain J, Rabbani I, Aslam S \& Ahmad $\mathrm{H}$ (2015). An overview of poultry industry in Pakistan. World's Poult Sci J 71(4): 689700 .

2. Ahmad Z, Naeem K \& Hameed A (2014). Detection and seroprevalence of infectious bronchitis virus strains in commercial poultry in Pakistan. Poult Sci 86: 13291335.

3. Marien M, Decostere A \& Duchateau L (2007). Efficacy of enrofloxacin, florfenicol and amoxicillin against Ornithobacterium rhinotracheale and Escherichia coli $\mathrm{O} 2: \mathrm{K} 1$ dual infection in turkeys following APV priming. Vet Microbiol 121: 94-104.

4. Siddique N, Naeem K \& Ahmed Z (2016). Isolation and sequence analysis of reassortant low pathogenic avian influenza virus H4N6 from duck and chicken in live bird markets from Pakistan. Pak Vet J 36: 258-263.

5. Antiabong JF, Haruna ES \& Owolodun J (2005) Isolation of Mannheimia (Pasteurella) haemolytica serotypes A2 and A12 from clinically ill and dead chickens: a case report. Tropical Vet 23: 61-64.

6. Ashraf A, Tariq H \& Shah S (2011). Characterization of Pasteurella multocida strains isolated from cattle and buffaloes in Karachi, Pakistan. Afr J Microbiol 5: 4673-4677.
7. Simon GS \& Okoth EO (2016). Species richness and abundance of birds in and around Nimule National Park, South Sudan. Sci 4: 92-4.

8. Roussan DA, Haddad \& Khawaldeh G (2008). Molecular survey of avian respiratory pathogens in commercial broiler chicken flocks with respiratory diseases in Jordan. Poult Sci 87: 444-448.

9. Pang Y, Wang H, Girshick T, Xie Z \& Khan MI (2002). Development and application of a Multiplex Polymerase Chain Reaction for Avian Respiratory Agents. Avian Dis 46: 691-699.

10. Hafez MH (2002). Diagnosis of Ornithobacterium rhinotracheale. Inter $J$ of Poult Sci 1: 114-118.

11. Ley DH, Barnes YM, Glisson JR, Fadly AM, McDougald LR \& Swayne DE (2003). Mycoplasma gallisepticum infection. In Saif. Editions. Diseases of Poultry, 11th edition. Iowa State Univ Press Ames Iowa 722-744.

12. Chin R, Ghazikhanian GY \& Kempf I (2003). Mycoplasma meleagridis infection. Diseases of poultry 11th ed Iowa, USA: Iowa Univ Press 744-756.

13. Suarez DL, Swayne DE, glisson Jr, McDougald Lr, Nolan LK, Suarez DL \& Nair V (2013). Colibacillosis editions, Diseases of Poultry 13th ed. Iowa State Press, Iowa 751-805.

14. Barnes HJ, Nolan LK \& Vaillancourt JP. Colibacillosis, Diseases of poultry, 12th edition 2008, pp 732.

15. Rodriguez-Siek KE, Giddings CW, Doetkott C, Johnson TJ, Fakhr MK \& Nolan LK (2005). Comparison of Escherichia coli isolates implicated in human urinary tract infection and avian colibacillosis. Microbiol 151: 2097-2110.

16. Moulin-Schouleur $M$, Répérant $M$, Laurent S, Brée A, Mignon-Grasteau S, Germon P, Rasschaert D \& Schouler C. (2007). Extraintestinal pathogenic Escherichia coli strains of avian and human origin: link between phylogenetic relationships and common virulence patterns. J Clin Microbiol 45: 3366-3376. 
17. Stenutz R, Weintraub A \& Widmalm G (2006). The structures of Escherichia coli O-polysaccharide antigens. FEMS Microbiol Rev 30(3): 382-403.

18. La Ragione RM \& Woodward MJ (2002). Virulence factors of Escherichia coli serotypes associated with avian colisepticaemia. Research in Vet Sci 73: 27-35.

19. Giovanardi D, Campagnari E, Ruffoni LS, Pesente P, Ortali G \& Furlattini V (2005). Avian pathogenic Escherichia coli transmission from broiler breeder to their progeny in an integrated poultry production chaina. Avian Pathol 34: 313318.

20. Petersen A, Christensen JP, Kuhnert P, Bisgaard M \& Olsen JE (2006). Vertical transmission of a fluoroquinoloneresistant Escherichia coli within an integrated broiler operation. Vet Microbiol 116: 120-128.

21. Temple LM, Miyamoto DM, Mehta M, Capitini CM, Von Stetina S, Barnes HJ, Christensen VL, Horton JR, Spears PR \& Orndorff PE (2010). Identification and characterization of two Bordetella avium gene products required for hemagglutination. Infect Immun 78: 23702376

22. Loker SB, Temple L.M \& Preston A (2011). The Bordetella avium fimbrial locus is regulated by temperature and produces fimbriae involved in adherence to turkey tracheal tissue. Infect Immun 79: 2423-2429.

23. Stockwell SB, Kuzmiak-Ngiam H, Beach NM, Miyamoto D, Fernandez R \& Temple $\mathrm{L}$ (2011). The autotransporter protein from Bordetella avium, Baa1, is involved in host cell attachment. Microbiol Res 167: 55-60.

24. Register KB \& Yersin AG (2005). Analytical verification of a PCR assay for identification of Bordetella avium. $J$ of Clin Microbiol 43: 5567-5573.

25. Koidl C, Bozic M, Burmeister A, Hess M, Marth E \& Kessler HH (2007). Detection and differentiation of Bordetella species by real-time PCR. J Clin Microbiol 45: 347-350.

26. Blackall PJ, Christensen H, Beckenham T, Blackall LL \& Bisgaard M (2005). Reclassification of Pasteurella gallinarum, Haemophilus paragallinarum, Pasteurella avium and Pasteurella volantium as Avibacterium gallinarum gen. nov., comb. Nov., Avibacterium paragallinarum comb. Nov, Avibacterium avium comb. Nov. and Avibacterium volantium comb. Int $J$ Syst Evol Micr 55: 353-362.

27. Blackall PJ, Soriano EV, Glisson JR, McDougald LR, Nolan LK, Suarez DK, Nair V \& Ames (2013). Infectious coryza and related bacterial infections, 13th edition, pp 859-874.

28. Olayinka AT, Olayinka BO \& Onile BA (2009). Antibiotic susceptibility a plasmid pattern of Pseudomonas aeruginosa from the surgical unit of university teaching hospital in north central Nigeria. Int J Med Sci 1:3: 079-083

29. Brown P D \& Izundu A (2004). Antibiotic resistance in clinical isolates of Pseudomonas aeruginosa in Jamaica. Pan American J Public Health 16(2): 12513.

30. Xiao K, Liu Q, Liu X, Hu Y, Zhao X \& Kong Q (2016). Identification of the avian Pasteurella multocida phoP gene and evaluation of the effects of phophorus deletion on virulence and immunogenicity. Int J Mol Sci 17(1): 12.

31. Biswas PK, Biswas D, Ahmed S, Rahman A \& Debnath NC (2005). A longitudinal study of the incidence of major endemic and epidemic diseases affecting semi scavenging chickens reared under the Participatory Livestock Development Project areas in Bangladesh. Avian Pathol 34: 303-312.

32. Marza AD, Abdullah FF, Ahmed IM, Chung EL, Ibrahim HH, Zamri-Saad M, Omar AR, Bakar MZ, Saharee AA, Haron AW \& Lila MA (2015). Involvement of nervous system in cattle and buffaloes due to Pasteurella multocida $\mathrm{B}: 2$ infection: A review of clinicopathological and 
pathophysiological changes. $J$ Adv Vet Anim Res 2: 252-262

33. Christensen JP, Bojesen AM \& Bisgaard M (2008). Fowl cholera. Poult Dis. 1(6):149-54.

34. Harper M, Boyce JD \& Adler B (2006). Pasteurella multocida pathogenesis 125 years after Pasteur. FEMS Microbiol Letters 265: 1-10.

35. Wang C, Wu Y, Xing X, Hu G, Dai J \& He $H$ (2009). An outbreak of avian cholera in wild waterfowl in Ordos wetland, Inner Mongolia, China J Wildl Dis 45: 11941197

36. Jensen EL \& Miller CL (2001). Staphylococcus Infections in Broiler Breeders. Avia Tech 1: 1-4.

37. Momtaz H, Dehkordi FS, Rahimi E, Asgarifar A \& Momeni M (2013). Virulence genes and antimicrobial resistance profiles of Staphylococcus aureus isolated from chicken meat in Isfahan province, Iran. J App Poult Res 22: 913-921

38. Songer JG (2005). Post KW. Veterinary microbiology. Bacterial and fungal agents of animal disease. Copyright $(0$. Elsevier Inc, pp 35-42.

39. Zouharova M, Rysanek D. Multiplex PCR \& RPL (2008). Identification of S.aureus enterotoxigenic strains from bulk tank milk. J Zoonos Publ Health 55(6): 313319.

40. Cunha MD, Peresi E, Calsolari RA \& Araujo Junior JP (2006). Detection of enterotoxins genes in coagulase-negative Staphylococci isolated from food. Brazil J Microbiol 37: 70-74.

41. Clavel $\mathrm{T}$, Charrier $\mathrm{C} \&$ Haller D (2013). Streptococcus a novel bacterium isolated from the caecum of a mouse. Arch Microbiol 195: 43-49.

42. Chadfield MS, Christensen JP, Christensen H \& Bisgaard M (2004). Characterization of streptococci and enterrococci associated with septicemia in broiler parents with higher prevalence of endocarditis. Avian Pathol 33: 610-617.
43. Hoshino T, Fujiwara T \& Kilian M (2005). Use of phylogenetic and phenotypic analyses to identify non hemolytic streptococci isolated from bacteremic patients. J Clin Microbiol 43: 6073-6085.

44. Gupta A, Ezzeldin T \& Agrawal P (2009). Mycoplasma complicated chronic respiratory disease.

45. Tsai HJ \& Lee CY (2006). Serological survey of racing pigeons for selected pathogens in Taiwan. Acta Veterinaria Hungarica 54: 179-189

46. Gharaibeh S \& Hailat A (2011). Mycoplasma gallisepticum experimental infection and tissue distribution in chickens, sparrows and pigeons. Avian Pathol 40: 349-354.

47. Feberwee A, Mekkes DR, Klinkenberg D, Vernooij JC, Gielkens AL \& Stegeman JA (2005). An experimental model to quantify horizontal transmission of Mycoplasma gallisepticum. Avian Pathol 34: 355-361

48. Landman WJ (2014). Is Mycoplasma synoviae outrunning Mycoplasma gallisepticum, A viewpoint from the Netherlands. Avian Pathol 43: 2-8.

49. Ahmad A, Rabbani M, Yaqoob T, Ahmad A, Shabbir MZ \& Akhtar F (2008). Status of IgG antibodies against Mycoplasma gallisepticum in non-vaccinated commercial poultry breeder flocks. International. J of Poult Sci 18: 61-63.

50. Hanif A \& Najeeb MI. (2007). Comparison of conventional bacterial isolation, rapid slide agglutination and polymerase chain reaction for detection of Mycoplasma gallisepticum in breeder flocks. Pakistan. J Life Soc Sci 5: 1-5.

51. Mukhtar M, Awais MM, Anwar MI, Hussain Z, Bhatti N \& Ali S (2012). Seroprevalence of Mycoplasma gallisepticum among commercial layers in Faisalabad, Pakistan. J Basic Appl Sci 8: 1

52. Muhammad A, Muhammad S, Sarzamin K, Qureshi MS, Naeem K, Muhammad R \& Muhammad M (2010). Prevalence of Avian Influenza and its economic impact on poultry population of Hazara region Pakistan. Sarhad j of Agri 26: 629-633. 
53. Cruickshank R, Duguid JP, Marmion BP \& Swain RH (1975). Medicinal Microb, Vol II, 12 th, edn. Edinburg, Churchill Livingstone pp 403-404.

54. Popy N, Asaduzzaman M, Miah MS, Siddika A, Sufian MA \& Hossain MM (2011). Pathological study on the upper respiratory tract infection of chickens and isolation, identification of causal bacteria. Bangla Vet 28(2): 60 - 69

55. Hussein AA \& Ismail HM (2014). Isolation and Identification of Aerobic Bacteria Associated with Respiratory Tract Infection in Chickens in Khartoum State, Sudan. $J$ vet Med and anim prod 150-158.

56. Hirsh D, Maclachlan NJ, \& Walker RL (2004). Veterinary Microbiology, $2^{\text {nd }}$ edition.

57. Linzitto OR, Abeiro HD, Benitez RN \& Menedez (2010). Bacteriological and clinical studies of infectious coryza. Revista De Medicina Veterinaria, Buenos Aires 69: 98101.

58. Elhassan MA \& Elsanousi SM (2004). Biological characteristics of Klebsiella strains isolated from man and animal. Sudan J Vet Sci Anim Husb 41(1, 2).

59. Georgiades G, Iordanidis P \& Koumbati M (2001). Cases of swollen head syndrome in broiler chickens in Greece. Avian Dis 45: 745-750

60. Murakami S, Miyama M, Ogawa A, Shimada J \& Nakane T (2002).
Occurrence of conjunctivitis, sinusitis and upper region tracheitis in Japanese quail (Coturnix coturnix japonica), possibly caused by Mycoplasma gallisepticum accompanied by Cryptosporidium sp. infection. Avian Pathol 31 363-370.

61. Youssef FM, Mona AA \& Mansour DH (2008). Some studies on bacteriological aspects of air sacculitis and epidemiological in poultry. Assiut Vet Med J 54(118): 284-300

62. Ibrahim RS, Mousa S, Aly M, Abdel \& Naser WE (2004). Complicated infectious coryza in broiler and layer chickens in Egypt. Assiut Vet Med J 50(103): 90-130

63. Türkyilmaz S (2006). Isolation and serotyping of Ornithobacterium rhinotracheale from poultry. Turk $J$ Vet and Animal Sci 10(29(6)): 1299-1304.

64. Husseina SA, Hassanb AH \& Sulaimanc RR (2008). Bacteriological and pathological study of yolk sac infection in broiler chicks in sulaimani district. $J$ of Dohuk Uni 11(1): 124-127.

65. Rahman MA, Samad MA, Rahman MB \& Kabir SM (2004). Bacteriopathology of salmonellosis, collibacillosis, pasteurellosis in natural and experimental infections in chickens. Bangl J Vet Med 2(1): $1-8$

66. Abubakar $M$, Irfan $M$ \& Manzoor $S$. (2015). Bacterial infections in chickens. $J$ Poul Sci 57: 32. 